\title{
The missing in the aftermath of war: When do the needs of victims' families and international war crimes tribunals clash?
}

\author{
Eric Stover and Rachel Shigekane*
}

History counts its skeletons in round numbers. A thousand and one remain a thousand as though the one never existed ${ }^{1}$.

One hot summer evening in 1999, Kevin Berry and his team of British investigators suddenly found themselves surrounded by a throng of angry villagers in south-western Kosovo. Berry's group was one of over a dozen teams of forensic scientists sent to Kosovo by the International Criminal Tribunal for the former Yugoslavia (ICTY) to investigate a series of massacres allegedly committed by Yugoslav forces earlier that spring. Their mission was to determine if there had been a pattern in the mayhem: What methods did the perpetrators use to dispatch their victims? Were the methods similar at different execution sites? And did the perpetrators make an effort to cover their tracks?

For six sweltering weeks, Berry and his team had worked closely with the inhabitants of Mala Krusa locating and exhuming mass graves in the rubble-strewn village. Then one day a rumour spread there that Berry and his team had gathered all the evidence they needed and would be leaving for another village. "It was a tense moment", Berry recalled. "We'd received orders that afternoon to move on and somehow the villagers had caught wind of it. They were concerned that we would leave with our work unfinished." Faced with a clash between the evidentiary needs of the ICTY for only certain kinds of evidence and the needs of the villagers, Berry opted to stay in Mala Krusa and finish all of the exhumations. "The villagers were right", he said later. "They were waiting for their loved ones to be recovered. It would have been disrespectful to leave."

* Eric Stover is the Director of the Human Rights Center and Adjunct Professor of Public Health at the University of California, Berkeley. Rachel Shigekane is Senior Program Officer at the Human Rights Center and Lecturer in Peace and Conflict Studies. 
Kevin Berry's encounter with the villagers of Mala Krusa illustrates a growing tension that has emerged in the past ten years between the humanitarian needs of families of the missing and the evidentiary needs and limitations of international war crimes tribunals in the aftermath of mass killings. On one side are families who wish to know the fate of their missing relatives and, if they have died, to receive their remains. As the Argentine Forensic Anthropology Team (EAAF), which has conducted exhumations in more than twenty countries over the past sixteen years, notes: "[F]amilies have a desperate need to recover the remains so that they may properly bury them and close - if only partially - the circle of uncertainty." ${ }^{3}$ Moreover, under Additional Protocol I to the Geneva Conventions of 1949, families have the right to know the fate of their missing relatives. ${ }^{4}$

On the other side are international war crimes tribunals, which are charged with investigating large-scale killings but may lack the resources or political will to undertake forensic investigations aimed at identifying all of the dead. When a tribunal does levy charges of genocide or crimes against humanity - the two most heinous of all state-sponsored crimes - against suspected high-level perpetrators of mass killings, personal identification of the victims may not be a necessary part of a legal investigation. The charge of genocide, for example, requires that the prosecution prove that the alleged perpetrators committed acts with the intent "to destroy, in whole or in part, a national, ethnic, racial or religious group", ${ }^{5}$ As such, particular persons became victims because of how they were perceived by the perpetrators. ${ }^{6} \mathrm{~A}$ forensic investigation will then focus on ascertaining the "categorical identification" of the dead, such as the victims' ethnicity, religion or race, and the

1 Wislawa Szymborska, "Hunger camp at Jasko", in Carolyn Forche (ed.), Against Forgetting: Twentieth Century Poetry of Witness, W.W. Narton, New York, 1993, p. 459.

2 Kevin Berry was interviewed by one of the authors (Stover) for National Public Radio in July 1999. Also, see Fred Abrahams, Gilles Peress, and Eric Stover, A Village Destroyed: May 14, 1999, War Crimes in Kosovo, University of California Press, Berkeley, CA, 2002.

3 See Mimi Doretti and Luis Fondebrider, "Science and human rights - Truth, justice, reparation and reconciliation: A long way in Third World countries", in V. Buchli and L. Gavin (eds), Archaeologies of the Contemporary Past, Routledge, London, 2001.

4 Protocol Additional to the Geneva Conventions of 12 August 1949, and relating to the Protection of Victims of International Armed Conflicts, of 8 June 1977 (hereinafter Protocol I), Art. 32.

5 Convention on the Prevention and Punishment of the Crime of Genocide, 78 U.N.T.S. 277, adopted by Resolution 260 (III) A of the General Assembly of the United Nations on 9 December 1948 Art.2.

6 See William D. Haglund, "Recent mass graves: An introduction", in William D. Haglund and Marcell Sorg (eds), Advances in Forensic Taphonomy, CPR Press, New York, 2001, pp. 243-262. 
cause and manner of death. Once these attributes have been established, the tribunal usually releases the remains to local forensic scientists to conduct the more difficult process of making personal identifications of the victims. Meanwhile, many families may continue to live with the uncertainty as to whether their missing loved ones are dead or alive.

Ideally, the relationship between the fainilies of the missing and international war crimes tribunals should be symbiotic, benefiting both the relatives and the courts but, in reality, it rarely is. Since the establishment of the two ad hoc international criminal tribunals for the former Yugoslavia and Rwanda in the early 1990s, only a small fraction of the remains of the missing have been identified and returned to families for proper burial. This can largely be attributed to the clandestine manner in which the bodies of the victims were disposed of, making their recovery difficult, if not impossible, without the cooperation of the actual perpetrators who for obvious reasons would rather remain anonymous. In Rwanda, the sheer number of dead (estimated between 500,000 and 800,000 ) has made it virtually impossible for the country's government or the International Criminal Tribunal for Rwanda (ICTR) to undertake large-scale forensic investigations. ${ }^{?}$ Finally, while the ICTY has been successful in identifying many of the dead at sites of small-scale massacres, it has chosen, largely for lack of resources, to forgo long-term identification projects at sites where the victims number in the thousands.

In this era of attention to international criminal justice and accountability, we need to develop a new, more comprehensive strategy for identifying and treating the remains of the dead in the aftermath of war, a coordinated strategy that satisfies both the humanitarian needs of the families of the missing and the legal needs of international war crimes tribunals. This article looks at the rationale for developing such a strategy.

\section{The search for the missing}

Recent history is replete with examples of situations where the International Committee of the Red Cross (ICRC) and other humanitarian and human rights monitoring organizations have been rendered powerless by 
military commanders and civilian leaders who disregard their obligations under international humanitarian law and block access to detainees and other vulnerable groups. One such incident took place in the summer of 1992, when Bosnian Serb authorities repeatedly denied an ICRC delegate access to three concentration camps near the central Bosnian town of Prijedor where thousands of Bosnian Muslims and Bosnian Croats were imprisoned in appalling conditions. ${ }^{8}$ Many of the detainees were summarily executed, while others died under torture or were starved to death..$^{9}$ It wasn't until a British television crew filmed the emaciated prisoners in one of the camps, sparking international outrage, that the camps were finally closed down. ${ }^{10}$

Another incident took place seven months earlier, on 20 November 1991, when a commander of the Yugoslav National Army (JNA), Army Major Veselin Sljivancanin, stopped an ICRC convoy from entering the grounds of the Vukovar hospital in eastern Croatia where hundreds of civilians were waiting to be evacuated. ${ }^{11}$ While the ICRC delegate argued with the JNA officer in an effort to gain access, Yugoslav troops removed 200 lightly wounded soldiers and hospital workers from the hospital and took them by bus to a farm called Ovcara nine kilometres south of the city. As night descended, the soldiers forced the men to stand in a freshly dug pit and then opened fire.

In October 1992, largely as a result of the suspected massacre on the Ovcara farm and the existence of so-called "death camps" in central Bosnia, the UN Security Council appointed a commission of experts to investigate reports of massive violations of international humanitarian law in the former Yugoslavia. ${ }^{12}$ Their findings, in turn, prompted the UN Security Council to

8 One of the camps, Omarska, alone held 3,000 or more prisoners. See The Prosecutor v. Kvocka et al. : Judgment, International Criminal Tribunal for the former Yugoslavia, Case No. ICTY IT-98-30/1, 2 November 2001, p. 8.

9 In its Judgment, the Tribunal noted that: "The evidence is overwhelming that abusive treatment and inhuman conditions in the camps were standard operating procedure (...). Many detainees perished as a result of the inhumane conditions, in addition to those who died as a result of the physical violence inflicted upon them." See The Prosecutor v. Kvocka et al. : Judgment, International Criminal Tribunal for the former Yugoslavia, Case No. ICTY IT-98-30/1, 2 November 2001.

10 Roy Gutman, Witness to Genocide, Macmillan Publishing, New York, 1993, p. 63. Two of the camps, Omarska and Keraterm, were closed in August 1992 and a third, Trnopolje, was closed in October 1992.

11 See Eric Stover and Gilles Peress, The Graves: Srebrenica and Vukovar, Scalo, Zurich, 1998, pp. 104-107.

12 See Final Report of the Commission of Experts Established Pursuant to Security Council Resolution 780 (1992), S/1994/674, 27 May 1994 and Annexes, S/1994/674/Add. 2 (Vol. I-V), 28 December 1994. 
establish the International Criminal Tribunal for the former Yugoslavia ${ }^{13}$ at The Hague in May 1993 to investigate alleged war crimes committed there following the disintegration of the Yugoslav State. After a Hutu-led slaughter claimed the lives of hundreds of thousands of people in Rwanda between April and July 1994, the UN Security Council established a second ad hoc tribunal in November $1994 .{ }^{14}$ Based in Arusha, Tanzania, the International Criminal Tribunal for Rwanda was charged with prosecuting war crimes and acts of genocide committed in that conflict. ${ }^{15}$ To gather physical evidence of war crimes the tribunals set up forensic units which, in turn, drew upon the expertise developed by forensic workers while investigating forced disappearances in Central and South America.

In the early 1970s, journalists and human rights groups first used the term "desaparecido", or "disappeared", to describe a particular form of government practice used to eliminate real and imagined government opponents in Latin America. But those who had "disappeared" hadn't really disappeared. Most of the "disappeared" had been abducted, tortured in secret detention centres, and then executed, their mutilated bodies discarded by the side of the road or buried in unmarked graves.

The first forensic investigation of the "disappeared" took place shortly after civilian rule returned to Argentina in 1983. Trained by American forensic anthropologist Clyde Snow, a team of medical and archaeology students set out to document the whereabouts of over 10,000 persons who had disappeared during the previous seven years of military rule. Known as the Argentine Forensic Anthropology Team (EAAF), the young scientists began collecting evidence for the trial of the nine members of the military junta. This aspect of their work was short-lived, however, as the new civilian government, faced with a string of military rebellions, enacted a series of laws in the late 1980 s that effectively amnestied all but a handful of military and police personnel. Still, the team persisted in their work, fuelled by the conviction that the families of the missing had a right to know the fate of their loved ones and to give them a proper burial. ${ }^{16}$

13 SC Res. 827, UN SCOR, 48th Session, 3217th Meeting, UN Document S/RES/827 (1993).

14 SC Res. 955, UN SCOR, 49th Session, 3453rd Meeting, Annex, UN Document S/RES955 (1994).

15 As of October 2002, 108 individuals are currently in proceedings before both the Rwandan and Yugoslav tribunals. So far, 41 accused have been tried, of whom 35 have been found guilty. See the

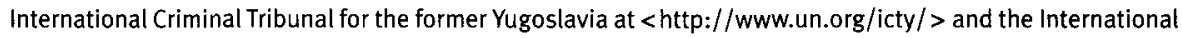
Criminal Tribunal for Rwanda at <http://www.ictr.org>.

16 See Christopher Joyce and Eric Stover, Witnesses from the Grave: The Stories Bones Tell, Little, Brown, Inc., Boston, 1991, pp. 215-305. 
Snow and his Argentine colleagues went on to train forensic teams in Chile and Guatemala in the early 1990s. The formation of the Guatemalan team was prompted by a declaration signed in 1992 by a coalition of family groups demanding a full accounting of the hundreds of thousands of people who were killed during Guatemala's 36-year civil war. "Peace will not come to Guatemala", the family groups declared, "as long as the remains of our massacred relatives continue to be buried in clandestine cemeteries and we cannot give them Christian burials". ${ }^{17}$

Like their Argentine counterparts, the Guatemalan team soon discovered that their findings would be admitted as evidence in only a handful of criminal trials. Consequently they gave priority to performing exhumations for the families of the missing and their communities. During the first days of an exhumation, family members would cluster near the graves. At first, they were often reluctant to speak to the scientists. Likewise, members of the forensic team recognized how important it was to let the relatives approach them at their own pace and in their own way. Invariably, after a day or so a group of women would draw near. A widow might produce a photograph of her missing husband and recount how he had disappeared.

Often not just families, but entire villages, would come to the exhumation sites in Guatemala. In the morning, women from the surrounding villages would kneel next to the grave and pray for the deceased. They would cook hot meals for the scientists during the day and volunteer to heft buckets of earth out of the grave. In the evenings, men from the village would leave their fields, help the scientists to cover the open pits with tarpaulins and carry their shovels and picks back to the villages. Such encounters were extremely important for the families of the missing. For years - even decades - the military, police, and courts had denied them information about their loved ones. Now, in the presence of scientists whose sole aim was to establish the truth, the relatives could begin to regain a sense of control and help in the process of locating their missing relatives.

Led largely by the Argentine and Guatemalan teams, and by two American organizations - the American Association for the Advancement of Science, and Physicians for Human Rights - the search for the disappeared spread in the mid-1990s from Latin America to other parts of the world.

17 Dawnie W. Steadman and William D. Haglund, “The anthropologist/archaeologist in international human rights investigations", paper presented at the Annual Meeting of the American Academy of Forensic Sciences, Seattle, Washington, 19 February 2001. 
By 1999, 97 forensic scientists from 20 countries had travelled, usually at the request not of governments but of family and human rights organizations, to 32 countries to investigate the whereabouts of the missing and to train local forensic scientists in the procedures of unearthing mass graves. ${ }^{18}$ Satellite imagery made it possible to generate maps to be used in pinpointing graves hidden in remote locations. Electronic mapping systems had replaced the standard archaeological technique of a baseline and string grid, which meant that the teams could save time and produce more accurate data. Most importantly, advancements in DNA analysis meant they could now identify the remains of individuals that had confounded more traditional anthropological methods.

\section{The legal and evidentiary needs of war crimes tribunals}

The first excavation of a mass grave under the auspices of the ad hoc international criminal tribunals for the former Yugoslavia and Rwanda took place in the grounds of a Roman Catholic Church in the western Rwandan town of Kibuye in December 1995. Out of the nearly 500 individuals exhumed at the church, leads could be established for only 17 persons. ${ }^{19} \mathrm{Six}$ carried identifying documents and eleven more had clothing or personal effects recognizable to acquaintances. None had hospital X-rays or dental records. For only two of the victims could surviving blood relatives be located. Soon after the Kibuye exhumation, the Rwanda tribunal ended its forensic programme. In the absence of other efforts to identify the dead, the remains of the vast majority of the victims - numbering in the hundreds of thousands - of the 1994 genocide remain unidentified.

Meanwhile, in the former Yugoslavia, the Office of the Prosecutor (OTP) of the ICTY launched its first investigation of mass graves in the spring of 1996. One of the five sites was the pit on the Ovcara farm containing what were believed to be the remains of the 200 patients and staff from the Vukovar hospital.

\section{The grave at Ovcara}

The Ovcara investigation represents one of the best case examples of how forensic efforts can satisfy both the legal and evidentiary needs of an international criminal tribunal and the humanitarian needs of families. 
As of October 2002, 184 of the Ovcara victims have been identified, largely on the basis of DNA analysis, and returned to relatives for burial. ${ }^{20}$ This relatively high success rate of identification can be attributed to a concerted effort on the part of the Croatian government to identify the victims, combined with the fact that the war had left Croatia's infrastructure relatively unscathed. Prior to the OTP exhumation, four years were devoted to collecting ante-mortem information; the Croatian government had moreover built a modern, state-of-the-art morgue at the medical school of the University of Zagreb for the exclusive use of OTP investigators. The government also trained Croatian geneticists in DNA analysis so that they could begin analysing the remains of those individuals which the OTP investigators could not identify using traditional anthropological methods.

From a legal and forensic perspective, the prosecution's case against the four accused in the Ovcara indictment was fairly straightforward. ${ }^{21}$ The Ovcara case, unlike subsequent investigations in Bosnia and Kosovo, involved a single crime - the murder of 200 people - at one location. Physical evidence of the crime was contained in a single mass grave that had been left undisturbed since the massacre. The OTP had numerous eyewitnesses who could confirm that one of the accused, the then Army Major Veselin Sljivancanin, had ordered the hospital patients onto the buses that took them to their deaths at the Ovcara farm. Other witnesses, mostly survivors of the massacre, could testify that Sljivancanin and the other codefendants - three military or paramilitary officers - were at the Ovcara farm on the day of the killings.

Finally, a high level of cooperation and information exchange among the organizations of the relatives of the missing, the OTP, and the Croatian government further contributed to the successful outcome. During the investigation, the OTP investigators and Croatian forensic scientists took the time to keep the relatives of the missing informed about developments in the case. Davor Strinovic, the Croatian forensic pathologist who took over the case from the OTP investigators, was especially responsive to the needs of the families. "Dealing with the mothers has been the most painful part of my work", he said later. "For nearly five years, they have waited for some kind of

20 Davor Strinovic (personal communication), Institute for Forensic Medicine and Criminology, Zagreb, Croatia, 11 October 2002.

21 See The Prosecutor of the Tribunal v. Mile Mrksic, Miroslav Radic, Veselin Sljivancanin, Slavko Dokmanovic, International Criminal Tribunal for the former Yugoslavia, Case No. IT-95-13a-I, 2 December 1997. 
news. Is he alive? Is he dead? Some mothers expected a miracle to happen, something God-sent, which would magically return their child. Then the day comes when the body's been identified and I have to inform the mother. I try to break the news kindly, but it is never easy. All those years of hope are shattered in a matter of seconds." ${ }^{22}$

\section{Genocide at Srebrenica}

In contrast to the Ovcara exhumation, the OTP's forensic investigation of the Srebrenica massacre yielded less salutary results for the families of the missing. Uprooted from their homes and villages, the survivors lived in squalid refugee camps and collective centres where they waited for news of their missing relatives. Because the massacre sites were behind enemy lines, they were unable to observe the exhumations and thus come to acknowledge, difficult though it was, that their loved ones might be dead. Denial nurtured hope, and when it was unfulfilled, frustration and anger took its place. At the same time, decisions were being made about the handling and investigation of the remains of the Srebrenica victims in which the families had no say.

The Srebrenica massacre began shortly after the Bosnian Serb army, under the command of General Ratko Mladic, seized the north-eastern Bosnian town on 11 July 1995. Declared a UN "safe area" two years earlier, the predominantly Muslim community had swollen from a pre-war population of 9,000 to 40,000 people, many of whom had been "ethnically cleansed" from elsewhere in Bosnia. As Mladic's troops swarmed over the town, the women, children and elderly took refuge two kilometres away on a UN base, staffed by a Dutch battalion, in the village of Potocari. Meanwhile, the remaining men and boys - some 10,000 to 15,000 — fled through the woods on foot, trying to reach Muslim-controlled territory almost 40 miles away. Over the next three days, General Mladic's army attacked or captured and executed over 7,500 men and boys, leaving bodies where they fell or burying them in graves scattered throughout the hills. The women and children who had taken refuge at the UN base were later transferred to Bosnian Muslim-controlled territory outside Tuzla. From collective centres and hastily erected tents, they began the wait for news of their missing relatives. ${ }^{23}$ 
On 16 November 1995, four months after the fall of the enclave, the ICTY Chief Prosecutor, Richard Goldstone, levelled additional charges of genocide against General Mladic and his civilian superior, Radovan Karadzic for their role in planning and carrying out the Srebrenica massacre. ${ }^{24}$ Four months earlier, the ICTY had also charged the two men with genocide for their role in the bombardment of civilians in Sarajevo. ${ }^{25}$ In May 1996, after the spring thaw, Goldstone dispatched a forensic team, assembled by Physicians for Human Rights, to begin the excavation of four of the suspected mass graves in the hills around Srebrenica. By the end of 1996, the scientists had unearthed approximately 517 bodies and assorted "disarticulated" body parts, autopsied them in a makeshift morgue to determine the cause and manner of death, and carefully preserved incriminatory evidence, such as ligatures and blindfolds. ${ }^{26}$ The bodies - all unidentified - were then released to the custody of the local Bosnian authorities who, lacking the means to grapple with the Srebrenica identifications, placed them in an abandoned tunnel cut into a hillside in Tuzla. In effect, the OTP had decided that the establishment of the victims' ethnicity and cause and manner of death would be enough to build their case of genocide against the principal perpetrators of the massacre, and that individual identifications were unnecessary. ${ }^{27}$

In the meantime, the Srebrenica survivors continued to insist that their relatives were alive. Rumours spread through the collective centres that their menfolk were languishing in Bosnian Serb prisons or working as forced labourers in mines across the border in Serbia. Many of the Srebrenica survivors blamed the Muslim authorities and the UN for failing to protect the enclave and prevent the loss of their menfolk. Rallies held by the Srebrenica families on behalf of the missing often turned violent. The most serious incident took place on 2 February 1996, when hundreds of women stormed the ICRC headquarters in Tuzla demanding that greater efforts be made to find their missing men.

24 See The Prosecutor v. Karadzic \& Mladic: Indictment, International Criminal Tribunal for the former Yugoslavia, Case No. ICTY IT-95-18, 16 November 1995.

25 See The Prosecutor v. Karadzic \& Mladic: Indictment, International Criminal Tribunal for the former Yugoslavia, Case No. ICTY IT-95-5, 24 July 1995.

26 See Eric Stover and Gilles Peress, op. cit. (note 11).

27 Laurie Vollen, "All that remains: Identifying the victims of the Srebrenica massacre", Cambridge Quarterly of Healthcare Ethics, Vol. 10, July 2001, pp. 336-340. 
Much of the women's rage focused on the ICRC's "death certificate" programme. Since the signing of the Dayton Peace Accords in December 1995, the ICRC, in its humanitarian tradition of trying to reunite families separated by war, had collected information on over 20,000 people who had disappeared on one side or another during the war in Bosnia. For a listing to be accepted, the ICRC required that a close relative submit the missing person's full name, father's name, date of birth, place of birth, and date and place where the victim was last seen. It then sent this information to the relevant authorities on the other side. Any answers provided were double-checked against the information provided by the wife and/or other witnesses who may have been present when the man disappeared. If the ICRC delegate was satisfied that the person was deceased, a "Certificate of Death", signed by an ICRC delegate, would be delivered to the family. In addition to ending the agonizing uncertainty, these documents were intended to help the next of kin obtain legal benefits such as pensions. But the death certificate programme caused a backlash; many, though not all, families were unwilling and unable to accept a "paper death". They claimed that their missing relatives were being written off, that the search for clandestine places of detention was inadequate, and that information was no substitute for bodies. In the autumn of 1997, the ICRC discontinued its death certificate programme in Bosnia. ${ }^{28}$

Throughout 1998 and 1999, both OTP and local Bosnian investigators continued to recover thousands of bodies and body parts from the hills of Srebrenica. Meanwhile, Physicians for Human Rights continued to collect ante-mortem information from the relatives of the missing. With no more space left in the tunnel, the remains were placed in containers in a parking lot, which further angered the family associations. Finally, in 2000, the International Commission on Missing Persons, established by President Clinton in 1996 to assist the families of the missing throughout the former Yugoslavia, built a new storage and morgue facility for the Srebrenica remains. The Commission also began an ambitious programme of DNA

28 In The Missing: ICRC Report (Summary of the Conclusions Arising from Events Held prior to the International Conference of Governmental and Non-governmental Experts, 19-21 February 2003 the ICRC states: "A death certificate alone might not be enough to induce belief in the death of a missing person. The authorities that issue death certificates have a responsibility, as does the ICRC when it delivers information on death, to ensure the authenticity of the information contained therein; the certificates should include information on the cause of death and the availability of the human remains." 
testing to identify the remains recovered from Srebrenica and throughout the former Yugoslavia. ${ }^{29}$

Today, nearly seven years after the fall of Srebrenica, over 500 victims have been positively identified, largely through DNA analysis. ${ }^{30}$ While recent DNA testing is showing promising results, identifying the dead from Srebrenica has proved more difficult than naming the remains exhumed from other mass graves in Bosnia and Croatia. Indeed, the statistical odds have been stacked against the Srebrenica investigators. Unlike the deceased in the Ovcara grave, the remains of the Srebrenica victims were spread over a large area and the vast majority had been stripped of personal documents, jewellery, and other potential leads to their identity. Bodies left in the open fell prey to scavengers who scattered the remains. In an effort to cover their tracks, Bosnian Serb soldiers used earth-moving equipment to exhume some of the graves and redeposit the remains in secondary graves. In the process, the remains were disarticulated, commingled, and crushed. ${ }^{31}$ Rather than initiating or encouraging another international entity to make a long-term effort to identify the Srebrenica victims, the OTP opted to turn over the remains to local forensic scientists who lacked both the resources and skills to do efficient investigative work themselves and thus set back the identification process by years.

\section{Widespread killings and command responsibility in Kosovo}

The OTP's next large-scale forensic investigation of war crimes in the former Yugoslavia began in mid-June 1999, days after NATO tanks rumbled into war-torn Kosovo. Over the next three months, the OTP shuttled more than 300 forensic scientists from 14 countries in and out of the region in what soon became the largest international forensic investigation of war crimes - or possibly of any crime - in history. Scotland Yard, the Royal Canadian Mounted Police and the FBI all sent teams, as did police agencies in Germany, Denmark, France, Belgium, the Netherlands and Switzerland. The FBI team, consisting of 64 people and 107,000 pounds of equipment,

29 See the website of the International Commission of Missing Persons, <http://www.ic-mp.org/icfact.asp>.

30 Edward Huffine (personal communication), International Commission of Missing Persons, 29 September 2002. According to Huffine, the total number of positive identifications of the Srebrenica dead will be near 1,000 by early 2003.

31 Testimony of William Haglund, The Prosecutor v. Krstic, International Criminal Tribunal for the former Yugoslavia, Case No. ICTY IT-98-33, 29 May 1999, T. 3722. 
even brought heavily armed agents from its Hostage Response Team to provide on-site security.

The forensic teams were charged with collecting physical evidence in support of an ICTY indictment issued against Yugoslav President Slobodan Milosevic and four high-ranking military and civilian leaders on 24 May 1999. The indictment charged the five co-defendants with crimes against humanity and violations of the laws of war for having "planned, instigated, ordered, committed or otherwise aided and abetted in a campaign of terror and violence directed against the Kosovo Albanian civilians living in Kosovo of the Federal Republic of Yugoslavia". ${ }^{32}$ The core of the tribunal's indictment was based on detailed accounts of massacres Yugoslav forces carried out against civilians in seven villages and towns throughout the province.

The most serious charge against Milosevic and his co-defendants was "crimes against humanity". ${ }^{33}$ The term originated in the Preamble to the 1907 Hague Convention, which codified the customary law of armed conflict. In 1915, the Allies accused the Ottoman Empire of crimes against humanity. Thirty years later, in 1945, the United States and its Allies incorporated it in the Nuremberg Charter, ${ }^{34}$ which served as the corpus juris for levying charges against Nazi leaders following World War II. Crimes against humanity encompass a wide range of abominable acts - mass murder, extermination, enslavement, deportation, rape, torture - committed against civilians on a large scale.

Whilst Milosevic and his co-defendants faced serious charges for their actions in Kosovo, punishable with life imprisonment, the OTP's forensic investigators had some serious investigative work ahead of them. In effect, they had to prove, beyond a reasonable doubt, that the crimes Yugoslav forces committed in villages and towns across Kosovo were not just an accident but had been planned and were widespread and systematic. As in the case of Srebrenica, the investigators did not need to identify every victim. Instead, they had to establish whether the victims were civilians and if the manner in which they were killed was similar in each of the seven villages and towns named in the indictment.

32 The Prosecutor v. Milosevic et al.: Indictment, International Criminal Tribunal for the former Yugoslavia, Case No. ICTY IT-02-54, 24 May 1999, para. 90.

33 Statute of the International Criminal Tribunal for the former Yugoslavia, adopted by UN Security Council Resolution 827 on 25 May 1993, Art. 5.

34 The Charter of the International Military Tribunal, annexed to the London Agreement for the Prosecution and Punishment of the Major War Criminals of the European Axis, of 8 August 1945, Art. 6(c). 
"In the absence of direct evidence of a plan to massacre these people", the OTP's Deputy Prosecutor Graham Blewitt said in July 1999, "we have to rely on circumstantial evidence. So proving patterns is important. We have to demonstrate that the tactics used by Yugoslav military, police, and paramilitary units in say, village $A$, were the same as those in village $B$, on or about the same day and thereafter in village $C$ and village $D$. We don't have to prove every single murder, or every single massacre, we just need to select a sample of these so that we can prove a pattern of killing and destruction aimed against civilians." 35

Blewitt's most difficult task in Kosovo, as it had been in the Ovcara and Srebrenica cases, was establishing "command responsibility" - namely, that Milosevic and his co-accused had either ordered or, having known that crimes were taking place, had failed to take all necessary and reasonable measures to prevent subordinates from committing such acts. ${ }^{36}$ Establishing the chain of command in Kosovo would require gathering testimonies from Kosovar Albanians who had witnessed war crimes in the seven villages and towns named in the indictment. It also meant obtaining documentary evidence, such as orders of troop deployments, notes from high-level meetings and intelligence intercepts of telephone conversations, that would demonstrate a systematic plan, conceived and implemented at a high level, to kill and terrorize civilians in those seven locations. Finally, establishing the chain of command would require an enormous forensic effort to exhume the mass graves in those areas to determine how the victims had been killed and disposed of. "Our aim in the forensic area," Blewitt said in July 1999, "is not to identify every single victim. We just don't have the resources to do it." In essence, the forensic experts were in Kosovo to corroborate witness testimonies and documentary evidence by identifying some of the victims of mass killings, determining how they had died, and demonstrating that the systematic and widespread nature of the killings suggested they had been planned in high places.

Given these evidentiary priorities, the OTP's forensic teams, with a few exceptions, did not set up formal procedures for gathering ante-mortem

35 Graham Blewitt, quoted in Abrahams, Peress, and Stover, op. cit. (note 2), p. 75.

36 The principle enunciating the responsibility of command responsibility derives from the principle of individual criminal responsibility applied by the Nuremberg and Tokyo Tribunals. It was subsequently codified in Art. 86(2) of Protocol I. 
information from the relatives of the missing. Nor did they routinely take bone or teeth samples from the remains they exhumed for future DNA analysis. In addition, the teams were under a great deal of pressure to investigate as many massacre sites as possible and to report their findings back to The Hague. This put the investigators in a difficult position vis-à-vis the local villagers who were waiting anxiously for the remains of their relatives to be exhumed and identified.

Today, nearly four years after the end of the war, approximately 4,500 bodies have been recovered from mass graves throughout Kosovo. ${ }^{37}$ Of these, half have been identified. ${ }^{38}$ Some of the identifications are a legacy of the ICTY's efforts immediately following the war. But many of the dead have been identified by local and international teams working solely for humanitarian purposes. Many of the bodies originally autopsied by ICTY forensic teams were left unidentified and then reburied haphazardly, without proper identifying markers. This has caused problems for forensic teams working with the United Nations Interim Administration Mission in Kosovo (UNMIK) and the International Commission on Missing Persons which later re-exhumed the bodies for identification purposes. In September 2002, the Commission launched a large-scale DNA-led identification process, similar to the programme underway in Bosnia..$^{39}$ In the meantime, the relatives of the missing have staged protests and hunger strikes throughout Kosovo, demanding that the process of identifying the dead be accelerated.

\section{The humanitarian needs of families}

No large-scale, cross-cultural study has ever been conducted to understand the long-term psychological impact of disappearances on the relatives of the missing. But anecdotal evidence and country-specific studies indicate that relatives of the missing can suffer "a sustained shock" as a result of "the anguish and pain caused by the absence of a loved one". ${ }^{40}$ Without the

37 ICTY investigators have also observed the exhumations of the remains of hundreds of Kosovar Albanians who were killed by Yugoslav forces during the war in Kosovo and later transferred to Serbia and buried in clandestine graves.

38 Jose-Pablo Baraybar, Director, Office on Missing Persons and Forensics, United Nations Interim Administration Mission in Kosovo (UNMIK), Press Statement, Pristina, Kosovo, 29 September 2002.

39 Press Statement, UNMIK, Pristina, Kosovo, 24 September 2002.

40 Amnesty International, "Disappearances": A Workbook, Amnesty International USA Publications, New York, 1981, p. 109. Also see Gregory I. Quirk and Leonel Casco, "Stress disorders of families of the disappeared: A controlled study in Honduras", Social Science and Medicine, Vol. 39, No. 12, 1994, pp. 1675-1679. 
remains of loved ones, families are caught in a limbo of "ambiguous loss", torn between hope and grief, unable to return to their past or plan for the future. ${ }^{41}$

Without bodies and funerals, the relatives of the missing are often unable to visualize the death of their loved ones and accept it as real. Nor can they fulfil their religious and communal obligations to the dead. Funerals express the emotional links of the living to the dead, be they of respect or grief. In some cultures and religious groups funerary rituals are explicitly carried out for the dead, but they are also rites of passage for the principal survivors, a mechanism for restoring the rent in the social fabric caused by death. Bosnian Muslims, for instance, view bereavement as an experience to be shared, strengthening the solidarity of family and community. For days and weeks after the burial, women and men may hold separate and, at times, collective prayers, or tevhids, for the departed. The most important aspect of the tevhid for the traditional Bosnian Muslim woman, in the words of anthropologist Tone Bringa, "is fulfilling her obligation to care for the spiritual well-being of deceased persons with whom her household has had close social relations, whether they were relatives, neighbors, or friends". ${ }^{42}$ For the Srebrenica survivors, and especially the women, the absence of bodies has robbed them not only of funerary ritual but of the visual cues that would help them to acknowledge the death of their loved ones and to pass through the states of mourning and grief.

When neighbours, friends and relatives join together to recite, eat, and talk at a tehvid, they bring the loss of the individual into the larger community. In her study of the reburial of bones from the Second World War in Yugoslavia, Katherine Verdery found that "[b]urials and reburials serve both to create and to reorder the community". ${ }^{43}$ They do so by bringing people together, through exchanges of food and objects, and through limiting the "community of mourners, all of whom think they have some relation to the dead person". In defining a group of mourners, funerals strengthen the sense that the individual does not suffer the grief alone.

Experience in several countries suggests that involving family members as observers at forensic exhumations can have positive results, especially if

41 See Pauline Boss, Ambiguous Loss: Learning to Live with Unresolved Grief, Harvard University Press, Cambridge, Mass., 1999.

42 See Tone Bringa, Being Muslim the Bosnian Way: Identity and Community in a Central Bosnian Village, Princeton University Press, Princeton, N.J., 1995, p. 194.

43 Katherine Verdery, The Political Lives of Dead Bodies: Reburial and Postsocialist Change, Columbia University Press, New York, 1999, pp. 107-108. 
they are able to observe both the technical skills required and the care that is taken to honour the dead. ${ }^{44}$ At the level of the individual, involving family members in tracking down ante-mortem information to help identify the deceased, such as medical records and X-rays, can partly ease feelings of helplessness or guilt for not having done more to find a missing relative. At the community level, exhumations can become a commemorative event that can facilitate the process of mourning. If conducted under the aegis of local or international institutions, exhumations can help individual mourners and whole communities to receive acknowledgement of their loss and move forward in the grieving process. ${ }^{45}$ The presence of family members at exhumations can also remind the forensic investigators of the human difference their work is making. ${ }^{46}$

According to Amani Trust, a Zimbabwean human rights organization, many family members of the missing in the western province of Matabeland have gone through tremendous psychological suffering because they have been unable to bury and mourn their dead according to local custom. In the Ndebele culture the dead play a significant role in the well-being of the living, and those who have not been given a proper burial can return as "a restless and vengeful presence, innocent yet wronged, aggrieved and dangerous to the living" ${ }^{47}$ In order for an ancestral spirit to fulfil its true task in protecting the family, it needs an honourable funeral followed by another traditional ritual known as "umbuyiso". During the winter months, approximately a year after the initial funeral, family elders take a goat to the grave of the deceased and allow his or her spirit to climb onto the animal's back. The spirit is then conveyed to the family home, where it goes through a ritual of being reintroduced to the living, and of being welcomed as an ancestor. This process brings the person's soul out of the wilderness and into the home to rest and to watch over the living.

In contrast to the legally-motivated exhumations of the ad hoc international criminal tribunals, Amani Trust conducts exhumations and reburials solely at the request of the families of the missing. "Our work is not about the

44 See Doretti and Fondebrider, op cit. (note 3).

45 Harvey M. Weinstein, "Where there is no body: Trauma and bereavement in communities coping with the aftermath of mass violence", paper presented at the ICRC Workshop on Support for Families of People Unaccounted For, Geneva, Switzerland, 10-11 June 2002.

46 Luis Fondebrider, "Reflections of the scientific documentation of human rights violations", paper presented at the ICRC Workshop on Human Remains: Law, Politics, and Ethics, Geneva, Switzerland, 23-24 May 2002.

47 See Shari Eppel, "Healing the dead to transform the living: The preventive implications", paper presented at the International Seminar on Torture and Organized Violence in the 21st Century, 24-26 January 2001, Copenhagen, Denmark. 
exhumation of hundreds or thousands of skeletons in a short space of time", writes Shari Eppel. "We are more concerned in exhuming a few graves and working closely with the families and communities over several years, in order to gain a more thorough understanding of how the process of exhumations and reburials can transform the lives of families and restore the social fabric" in the wake of widespread political violence. ${ }^{48}$ For instance, in the five adjacent villages where the Amani Trust has worked for the past four years, the collection of antemortem records from family members is used to conduct informal "testimony therapy". Over consecutive visits family members are encouraged to recall the complete history and habits of the deceased, something they may never have had the opportunity to do since the death. Amani workers also prepare family members for the pitfalls of exhumations, including the real possibility that the remains of the deceased may not be located or may reveal, upon post-mortem examination, that the deceased suffered great physical trauma prior to death.

Some individuals, families and entire communities in post-war societies may find it too painful to go through the process of identifying the dead, especially if the effort will take years. Or they may have other cultural needs that preclude individual identifications. Many of the Srebrenica survivors, for instance, believe that the construction of a memorial and a collective burial site for the anonymous dead should take precedence over individual identifications. In 2000 , these survivors lobbied successfully for a commemorative site to be built at a location near where the massacres took place. Their active participation in choosing the site and in its planning and design gave the survivors a sense of control over their own needs and ultimately of the mourning process that had been denied them for so many years.

These findings suggest that families should have more than just "a right to know the fate" of their missing loved ones; they should also be actively involved in the legal and humanitarian efforts to locate, exhume, rebury and memorialize the dead. ${ }^{49}$

\section{8 lbid.}

49 Psychologists dealing with survivors of trauma have long postulated that personal efficacy is a major determinant in recovery. In recovering from trauma, Judith Herman argues that "[n]o intervention that takes power away from the survivor can possibly foster her recovery, no matter how much it appears to be in her immediate best interest". See Judith Herman, Trauma and Recovery: The Aftermath of Violence from Domestic Abuse to Political Terror, Basic Books, New York, 1992, p. 134. Another way of examining this phenomenon is through the "control over one's destiny" hypothesis, developed by Leonard Syme, who holds that control over one's destiny refers to the ability "to influence the events that impinge upon our lives". According to Syme's research, a great sense of control in one's life often leads to better health outcomes. See S. Leonard Syme, "Social and economic disparities in health: Thoughts about intervention", The Millbank Quarterly, Vol. 76, 1998, pp. 493-505. 


\section{Integrating humanitarian and legal needs}

At the beginning of the 21 st century armed conflicts are increasing in number and ferocity. There are now over fifty wars raging in various parts of the world, and dozens of hot spots which could explode into violence at any moment. Meanwhile, the international community has finally taken seriously its obligations to prosecute war criminals. ${ }^{50}$ This in turn has created a growing demand for forensic expertise to investigate reports of war crimes and human rights abuses worldwide. In its 2000 report, the UN Office of the High Commissioner for Human Rights stressed that "the growing number of national conflicts generating gross and massive human rights violations has provided more impetus to the need to resort to forensic and related experts to identify the victims". ${ }^{51}$ This demand has resulted in the formation of nine forensic teams and programmes within non-governmental organizations dedicated to the medico-legal investigation of violations of international human rights and humanitarian law. The UN, through its Commission on Human Rights, has also created a list of 487 forensic experts who are available for human rights fact-finding missions. ${ }^{52}$

As more forensic scientists enter this growing field, the need to develop scientific and ethical standards and protocols relating to the exhumation and post-mortem examination of the remains of the missing is becoming apparent. Such guidelines should ensure that forensic investigations into the fate of the missing are conducted in a manner that serves the best interests of the families as well as bringing those responsible for these crimes to justice. After a year of consultations with forensic scientists, military personnel, legal experts and representatives of family and human rights organizations, the ICRC has called on forensic scientists working in the missing persons context to demonstrate a level of professionalism that goes beyond simply adhering to scientific standards. Forensic specialists, the ICRC argues, must also:

50 Besides the two ad hoc international criminal tribunals for Rwanda and the former Yugoslavia, a permanent International Criminal Court has been established to try persons accused of war crimes, crimes against humanity, and genocide. The Statute of the International Criminal Court, of 17 July 1998 (which entered into force on 1 July 2002) can be found at <http://www.un.org/law/icc/statute/.htm >.

51 Report of the United Nations Office of the High Commissioner for Human Rights, E/CN.4/2002/67, 21 January 2000.

52 lbid. The UN has also produced two documents - Manual for the Prevention of Extra-Legal, Arbitrary and Summary Executions and Guidelines for the Conduct of United Nations Inquiries into Allegations of Massacres - that set out the standards and procedures for investigating war crimes and violations of human rights. 
- be qualified and competent to work in the process of exhuming and conducting post-mortem examinations of the remains of missing persons;

- advocate the development of a process to identify the dead and observe and record all crime scene and post-mortem information potentially relevant to identification;

- refrain from destroying material that may be used for future identification purposes;

- consider the families' rights and needs before, during, and after exhumation;

- be familiar with the pertinent provisions of international humanitarian and human rights law, and promote their incorporation in forensic training programmes; and

- know the ethical boundaries of their work.

The underlying message is that forensic scientists must recognize that they have an obligation to the legal institutions that retain their services and to the families of the missing.

The ICRC has also recommended that an international network of forensic scientists be established to work on behalf of missing persons. ${ }^{53}$ This network should be guided by the principle that "[i]dentification for purposes of informing the family and returning remains is just as important as providing evidence for criminal investigations and constitutes due recognition of the rights of the families [emphasis added]". It should, among other things, develop and disseminate standards of practice and codes of ethical conduct; accredit laboratories to undertake DNA analysis; help train local and regional forensic teams which will be best suited to deal with local cultural customs and traditions; lobby governments to make forensic expertise and material resources available for national and international work; speak out on behalf of forensic scientists who face persecution for their professional activities; and develop mechanisms for debriefing and providing psychological assistance to forensic scientists.

In our view, such a network should be inclusive rather than exclusive. Its governing boards should include forensic scientists as well as representatives of family, human rights and humanitarian organizations; jurists who have worked with the ad hoc war crimes tribunals; anthropologists who are familiar with bereavement and funerary rituals in varying cultures and social 
settings worldwide; and mental health professionals experienced in post-war situations. The network should facilitate rather than dictate. Such an institution must not internationalize the search for the missing to such an extent that it undermines the capacity of local governmental and non-governmental institutions to develop culturally appropriate responses to what are ultimately local problems. The network must ensure that the families of the missing and the organizations that represent them have a voice in the processes that guide forensic investigations into the fate of the missing.

\section{Conclusion}

In the winter of 1984 , before leaving on his first forensic mission to Argentina to investigate the fate of the "disappeared," the American anthropologist Clyde Snow told a meeting of scientists in New York City: "Of all the forms of murder, none is more monstrous than that committed by a state (...). Maybe it's time for the forensic scientists of the world to (...) go after the biggest game of all." ${ }^{14}$ Eighteen years later, Snow and his colleagues can take pride in the contributions they have made to international criminal justice and the rule of law worldwide. The evidence these forensic scientists have so painstakingly collected has helped put dozens of war criminals and human rights violators behind bars. With the aid of DNA analysis, they have also helped countless families and communities to learn the fate of the missing and move forward in the grieving process.

Such progress notwithstanding, the challenge we face in today's increasingly violent world is to keep the primacy of international criminal law from supplanting our obligations to the living. Forensic scientists must continue to advocate for the dead. But, in doing so, they must not lose sight of the needs and rights of the survivors for whom justice is also sought. 


\section{Résumé}

\section{Les personnes portées disparues au lendemain d'un conflit}

\section{Eric Stover et Rachel Shigekane}

De plus en plus, les tribunaux pénaux internationaux pour l'ex-Yougoslavie et le Rwanda font appel à des experts légistes pour réunir des preuves scientifiques des massacres liés à des actes de génocide et des crimes contre l'humanité. D'une manière générale, ces investigations n'ont permis d'identifier qu'un petit nombre de défunts parce que les tribunaux ne disposent pas de ressources nécessaires pour mener des enquêtes approfondies, ou parce que les besoins en matière de preuve n'imposent pas d'identifier toutes les victimes. Entre-temps, les familles des personnes portées disparues sont laissées dans l'incertitude d'une "perte ambiguë», déchirées entre l'espoir et le chagrin, incapables de revenir sur le passé ou de se tourner vers l'avenir. Sans dépouille et sans funérailles, elles sont souvent dans l'incapacité de visualiser le décès de l'être cher et d'en accepter la réalité. En application du Protocole additionnel I aux Conventions de Genève de 1949, les familles ont le droit de connaître le sort de leurs proches. Afin de faciliter l'exercice de ce droit, il conviendrait de créer un réseau international d'experts légistes qui serait chargé d'élaborer et de diffuser des lignes directrices et des normes pratiques, ainsi que de coordonner les enquêtes humanitaires sur le sort des personnes portées disparues. Le réseau devrait être guidé par le principe qu'il est tout aussi important d'identifier les disparus que de recueillir des preuves pour les enquêtes pénales. 